\title{
NEW IN 2012
}

\section{Global Constitutionalism}

Human Rights Democracy Rule of Law

Global Constitutionalism - Human Rights, Democracy and the Rule of Law (GlobCon) seeks to promote a deeper understanding on the foundations, limitations and principles of political order and their dynamics over time on a global scale.

The journal is interested in work that refers to constitutionalism as a template for empirical, conceptual or normative research on past, present and future political and legal practices, within and beyond the state.

GlobCon invites submissions from scholars of International Law, Political Science, International Relations, Comparative Constitutional Law, Comparative Politics, Political Theory and Philosophy.

Published in Association with the Centre for Globalisation and Governance, University of Hamburg

Find out more about this exciting new journal including submission information here:

journals.cambridge.org/GlobCon UNIVERSITY PRESS 


\section{Cambridge Journals Collections}

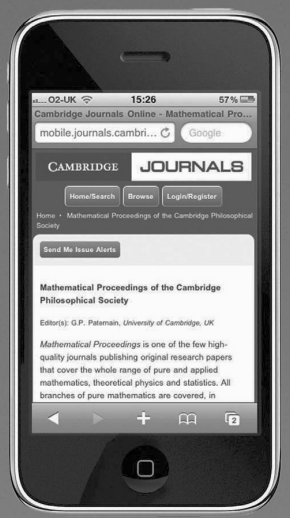

\section{Over 280}

leading titles online

As Complete Collection, HSS or STM

Via Cambridge Journals Online (CJO) or CJO Mobile (CJOm)

Please email: jnlsales@cambridge.org for further info

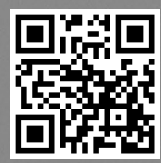

journals.cambridge.org

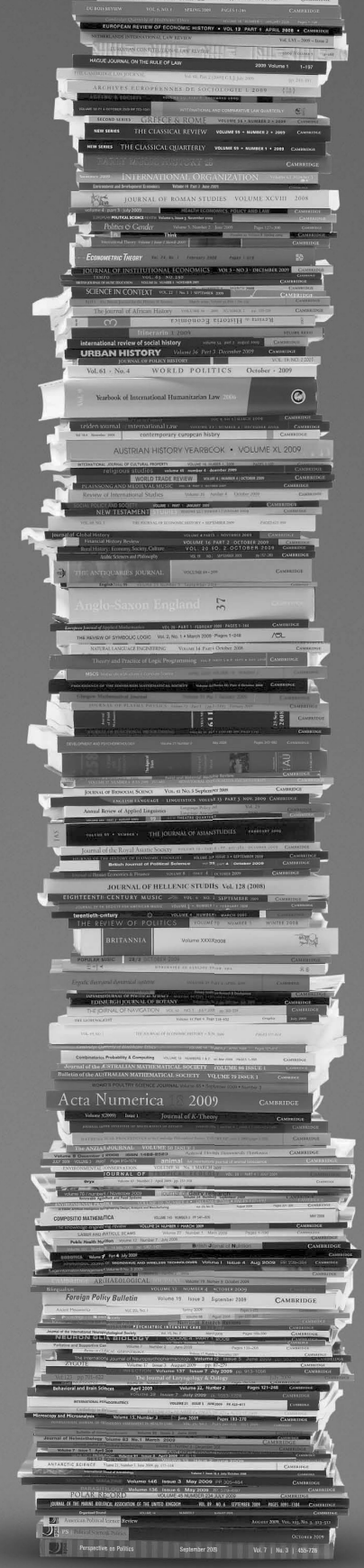




\section{JOURNALS}

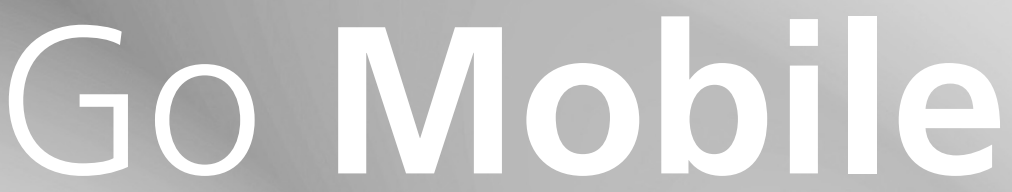

CJO Mobile $(\mathrm{CJOm})$ is a streamlined

Cambridge Journals Online (CJO)

for smartphones and other

small mobile devices

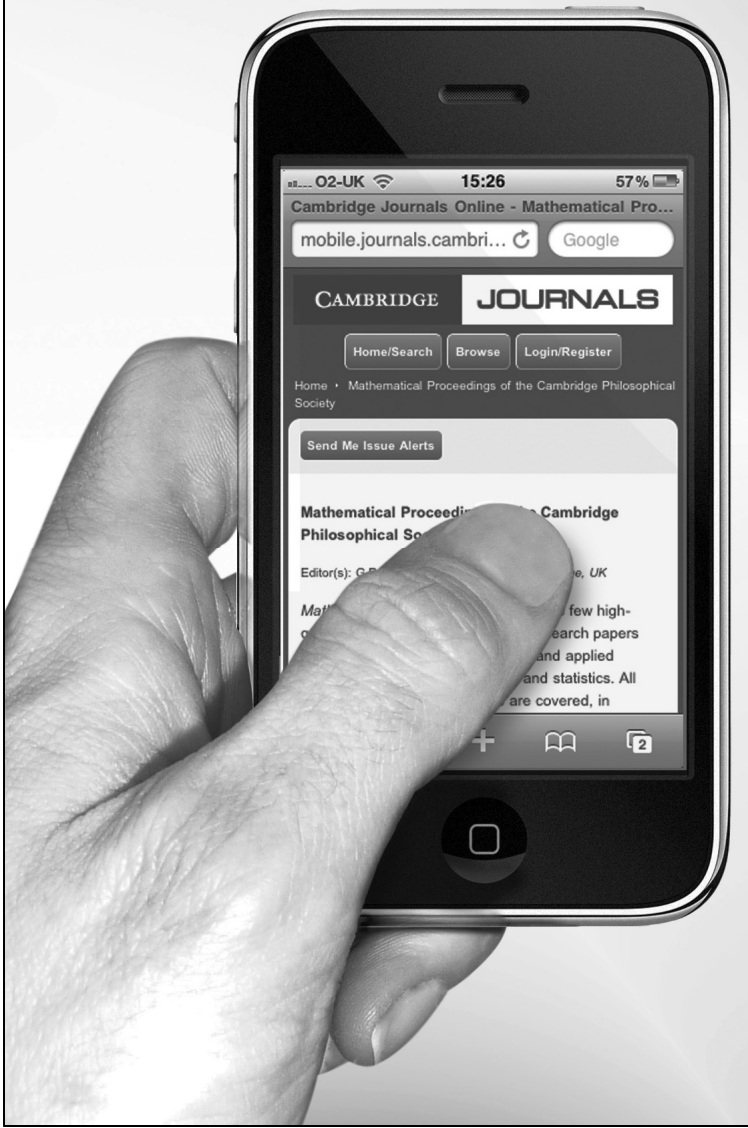

- Use CJOm to access all journal content including FirstView articles which are published online ahead of print

- Access quickly and easily thanks to simplified design and low resolution images

- Register for content alerts or save searches and articles they will be available on both CJO and CJOm

- Your device will be detected and automatically directed to CJOm via: journals.cambridge.org

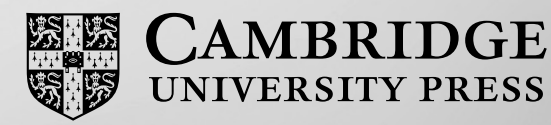




\section{CAMBRIDGE JDUNALS}

\section{Perspectives on Politics}

Published for the

American Political Science Association

\section{Editor}

Jeffrey C. Isaac, Indiana University, USA

Perspectives on Politics seeks to provide a space for broad and synthetic discussion within the political science profession and between the profession and the broader scholarly and reading publics. Such discussion necessarily draws on and contributes to the scholarship published in the more specialized journals that dominate our discipline. At the same time, Perspectives seeks to promote a complementary form of broad public discussion and synergistic understanding within the profession that is essential to advancing research and promoting scholarly community.

Perspectives seeks to nurture a political science public sphere, publicizing important scholarly topics, ideas, and innovations, linking scholarly authors and readers, and promoting broad reflexive discussion among political scientists about the work that we do and why this work matters.

Perspectives on Politics is sold ONLY as part of a joint subscription with American Political Science Review and PS: Political Science \& Politics.

To subscribe contact Customer Services

\section{in Cambridge:}

Phone +44 (0)1223 326070

$\mathrm{Fax}+44(0) 1223325150$

Email journals@cambridge.org

\section{in New York:}

Phone +1 (845) 3537500

Fax +1 (845) 3534141

Email

subscriptions_newyork@cambridge.org

\section{Free email alerts}

Keep up-to-date with new material - sign up at

journals.cambridge.org/register \\ http://journals.cambridge.org/pps}

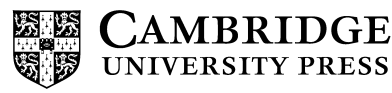




\section{NEW IN 2013}

\section{Political Science}

\section{Research and Methods}

THE JOURNAL OF THE EUROPEAN POLITICAL SCIENCE ASSOCIATION

Political Science Research and Methods (PSRM) is a general political science journal dedicated to publishing original scholarly work of the highest quality from all subfields of political science.

PSRM seeks research that applies rigorous methods to empirical or theoretical problems and promotes a rigorous scientific approach to the study of politics. Work at the intersection of political science and related disciplines such as economics and sociology is also welcomed.

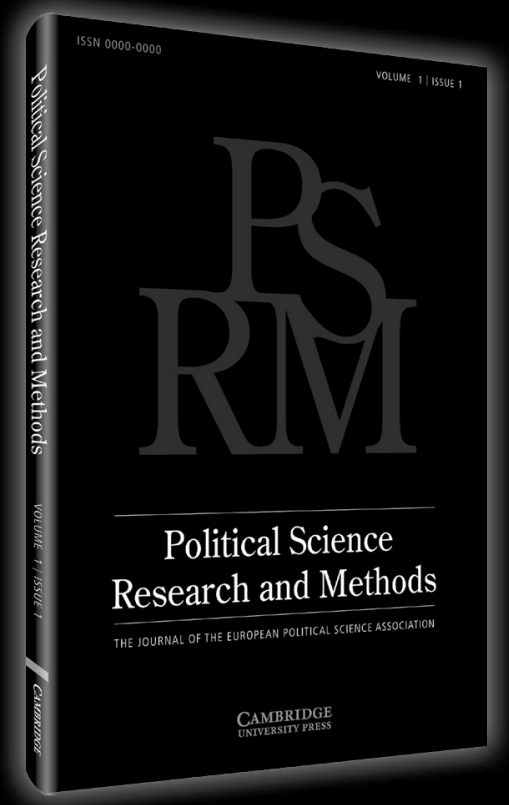

Sign up for content alerts, find out how to submit your paper, recommend PSRM to your librarian and more at the journal homepage here: journals.cambridge.org/prsm 


\section{Manuscripts}

The Editor welcomes the submission of materials for consideration as a main article or a review article. The approximate length required for main articles is 7,00o to 10,000 words, including notes. The Japanese Journal of Political Science is a refereed journal, and contributors should allow time for the process of refereeing to take place.

Manuscripts (MS-Word file) should be submitted electronically to the JJPS Editorial Office: jjpeditorial@cambridge.org

An abstract (no more than 250 words) together with a brief author profile (150 words or less) should accompany the submission. The author's name and affiliation must not appear on the main body of your manuscript, but only on a separate cover sheet. The desired location of tables and figures is to be indicated in the text, but all tables and figures are to be placed on separate sheets at the end of the article, following the notes and references. Tables and figures can be submitted in a separate file.

When an article has been accepted for publication after the process of review and revise, the author should submit a final version of the article in a Word file (MS-Word 2003 or later) to the editorial office of the Japanese Journal of Political Science as an e-mail attachment. All submissions must be typed in an unformatted Word document (no style is to be applied).

\section{References and Notes}

These are to be placed at the end of the submission, on separate sheets, and should be indicated serially within the article by superscript numerals. References should give full biographical details, including place of publication and the publisher, at first mention. Thereafter, the author's name and a short title should be used; op. cit. is not acceptable. A cross reference to the original citation (e.g., see n. 6 above) may also be added should the short title reference not be immediately clear. The title of articles should appear in single inverted commas, and the title of a book or journal should be in italics. Article and book titles in roman script are to be written as in the original. References and notes should be in the following form :

1 Robert Huckfeldt and John Sprague, Citizens, Politics and Social Communication (Cambridge: Cambridge University Press, 1995).

2 Ibid.p. 281.

3 T. J. Pempel and Keiichi Tsunekawa, 'Corporatism without Labor? The Japanese Anomaly', in Philippe Schmitter and Gerhard Lehmbruch (eds.), Trends towards Corporatist Intermediation (Beverly Hills: Sage Publications, 1979), pp. 23-26.
4 New York Times, 13 May, 1987.

5 Lester C. Thurow, Zero Sum, p. 24.

6 Junko Kato, 'When the Party Breaks Up: Exit and Voice among Japanese Legislators', American Political Science Review, 92, pp. 857-870.

7 Inoguchi Takashi and Iwai Tomoaki, Zoku Giin no Kenkyu [Research on Tribe Diet Members], Tokyo: Nihon Keizai Shimbunsha, 1987.

(The basic rule is that when Chinese, Korean and Japanese write in their respective language, then surname comes first and given name comes last, when Chinese, Korean and Japanese write in English, then the surname comes last and given name comes first.)

\section{Subheadings}

Contributors are encouraged to include up to two levels of subheading in articles to provide signposts for readers. These should be typed flush left, with only the first word and proper names written with an initial capital letter.

\section{General}

First proofs may be read and corrected by contributors provided that they can give the editor a current address and guarantee to return the corrected proofs, by e-mail where appropriate, within three days of receiving them.

\section{Copying}

The journal is registered with the Copyright Clearance Center, 222 Rosewood Drive, Danvers, MA, 01923, USA.

Organisations in the USA who are also registered with the CCC may therefore copy material (beyond the limits permitted by sections 107 and 108 of the US copyright law) subject to payment to CCC of the per-copy fee of $\$ 12.00$. This consent does not extend to multiple copying for promotional or commercial purposes. Code 1468-1099/12 \$12.00. Organisations authorised by the Copyright Licensing Agency may also copy material subject to the usual conditions. ISI Tear Service, 3501 Market Street, Philadelphia, Pennsylvania 19104, USA, is authorised to supply single copies of separate articles for private use only. For all other use, permission should be sought from Cambridge UK or the American Branch of Cambridge University Press. 


\section{JAPANESE JOURNAL OF POLITICAL SCIENCE VOLUME 14 PART 2 JUNE 2013}

\section{CONTENTS}

\section{Research Articles - Special Issue}

Introduction to Special Issue

Japan's Crisis Management amid Growing Complexity: In Search of New Approaches

Alexandra Sakaki and Kerstin Lukner - Guest Editors

Crisis Management, LDP and DPJ Style

Ellis Krauss

The Crisis Management Capability of Japan's Self Defense Force for UN Peacekeeping, Counter-Terrorism, and Disaster Relief

Katsumi Ishizuka

Financial Crisis Fatigue? Politics behind Japan's Post-Global Financial Crisis Economic Contraction

Saori N. Katada

DPJ's Political Leadership in Response to the Fukushima Nuclear Accident

Tomohito Shinoda

A Normal Accident or a Sea-Change? Nuclear Host Communities Respond to the $3 / 11$ Disaster

Daniel P. Aldrich

Reviews 